\section{MENTALLY ILLS IN THE IRANIAN CRIMINAL JUSTICE*}

\author{
LOS ENFERMOS MENTALES EN EL \\ JUSTICIA PENAL IRANÍ
}

\section{OS DOENTES MENTAIS NA JUSTIÇA PENAL IRANIANA}

Mansour Rahmdel ${ }^{a}$ mrrahmdel@yahoo.com Fecha de recepción: 09 de marzo de 2016 Fecha de revisión: 20 de abril de 2016 Fecha de aceptación: 02 de noviembre de 2016

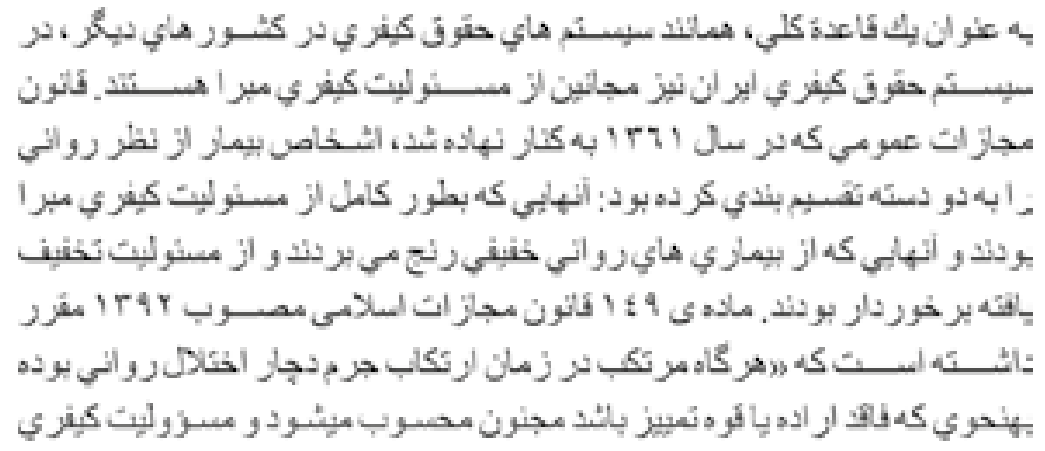

* This article is a Reflection article, which presents the results of an investigation from an analytical, interpretative perspective and with a review from the author about a specific subject with first hand sources.

a. Professor at Faculty of Law, Tehran Azad University, Central Branch, graduated from Tehran University, specialist in legal criminal institutions of the university with Master studies in criminal law, with a PhD degree on advanced studies in criminal law and criminology and drug crimes in Tehran University.

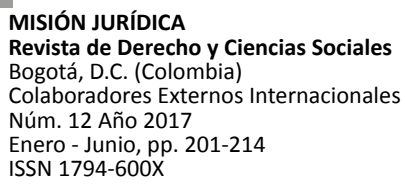

Bogotá, D.C. (Colombia)

Colaboradores Externos Internacionales Núm. 12 Año 2017

Enero - Junio, pp. 201-214

ISSN 1794-600X 


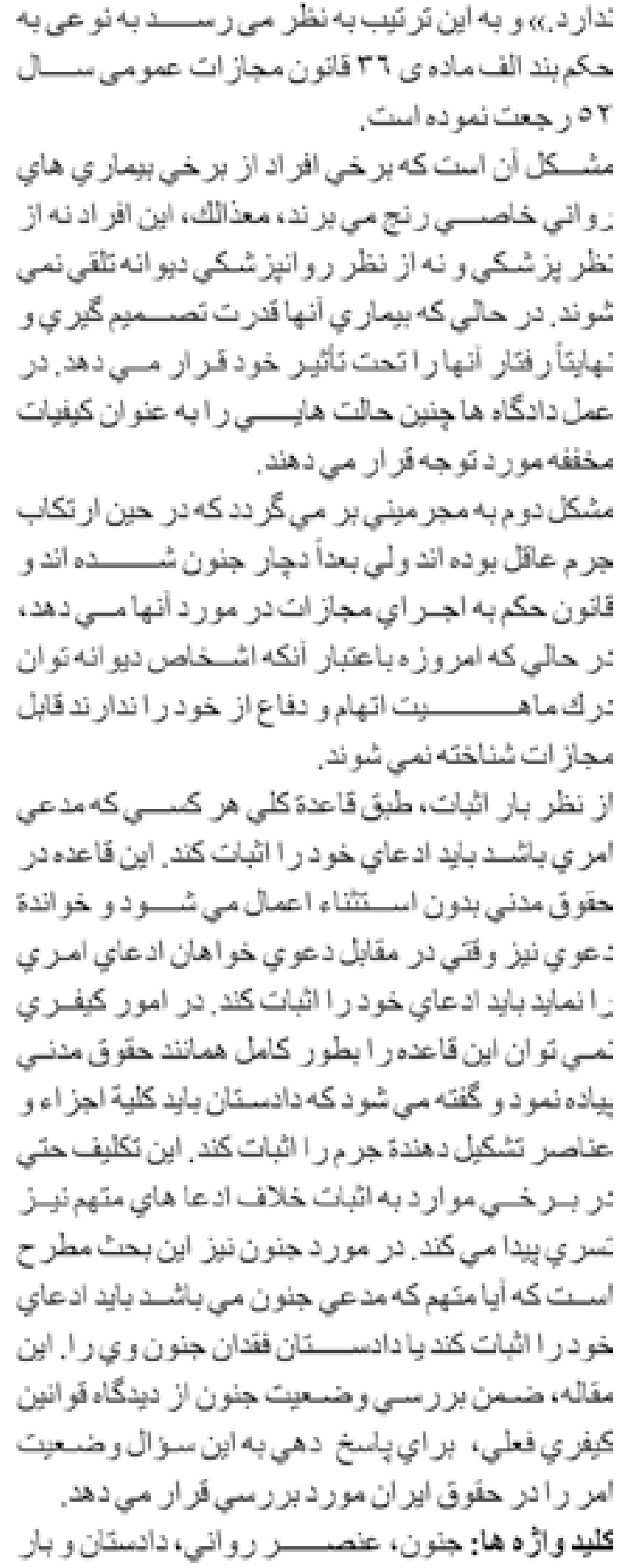

\section{ABSTRACT}

Similar to criminal legal systems in other countries, Iranian criminal law exempts people deemed to be insane from liability. The first penal Code, ratified in 1925, reformed in 1973, and abolished in 1982, had classified the mentally ill into two groups. Those who were completely insane were entirely exempt from criminal liability, but those who suffered from less severemental illnesses were only granted diminished liability. Section 149 of the Islamic Penal Code, which was ratified in 2013, holds that if the perpetrator is mentally disturbed at the time of committing the crime, such that they lack will or power of understanding, they are to be exempt from criminal liability. Therefore, it seems that the new code refers to item A of article 36 of the Iranian Penal Code, ratified in 1973.

The problem is that certain people suffer from less severe mental illnesses that, while still debilitating, are neither medically nor psychologically categorized as insanity. That is, although these illnesses influence both their faculty of decision-making and their behavior, the law recognizes these people as being fully criminally liable. Thus, apparently the former law held more conformity with scientific rules. In practice, courts regard such cases as instances of mitigating circumstances.

A second problem is with cases where the offenders were sane when committing the crime, but have since then lost their sanity, yet the law still pronounces them as fully liable to punishment. Nowadays, it is an accepted rule that the insane are not punishable, because, whoever is incapable of comprehending the accusation and punishment should not be punished.

Regarding the burden of proof, in accordance to a general rule, he who asserts must prove. This rule is applied in civil law without exception, and dictates that the defendant, who asserts something, must prove their claim. Regarding criminal cases, however, this rule could not be applied like civil law and it is stipulated that the prosecutor must prove all of the elements comprising the crime in question. The burden of proof, even when the accused asserts something, is on the prosecutor. Regarding insanity, the question is whether ot not the burden of proof is to be on the accused claiming insanity, or rather that the prosecutor must disprove the claim made 
by the accused. Thisarticle attempts to find an answer to this question and different dimensions of insanity and criminal liability, and reviews the conditions in the Iranian criminal law.

\section{KEY WORDS}

Mentally ill, insanity, Iran, justice.

\section{RESUMEN}

Por lo general, como todos los otros sistemas jurídicos penales en otros países, las personas dementes están exentas de responsabilidad penal en el derecho penal iraní. El primer código penal ratificado en 1925, reformado en 1973 , abolido en 1982 , ha clasificado a los enfermos mentales en dos grupos. Aquellos que eran dementes por completo estaban libres de responsabilidad penal, pero otros quienes padecían enfermedades mentales leves tenían una responsabilidad penal atenuada. La sección 149 del Código Penal islámico de Irán ratificado en 2013 sostiene que si el criminal está mentalmente perturbado en el momento de cometer el crimen, al punto en que carece de voluntad o capacidad de entendimiento, está exento de responsabilidad penal. Por eso parece que el nuevo código hizo referencia al item A del artículo 36 de la justicia penal iraní, ratificada en 1973.

El problema es que algunas personas sufren de una enfermedad mental particular o sufren de una enfermedad mental leve, no obstante, ellos no están clínicamente o psicológicamente dementes. Esto significa que, aunque estas enfermedades influencian tanto su facultad para tomar decisiones y por lo tanto su comportamiento, la ley reconoce a estas personas como con responsabilidad penal plena. Entonces, la ley anterior aparentemente estaba más de conformidad con las reglas científicas. En la práctica las cortes consideran esos casos como instancias que mitigan circunstancias.

Hay un segundo problema con los casos donde los delincuentes, que estaban cuerdos al momento de cometer el crimen, después dejaron de estarlo, y la ley también los declara pasibles de ser sancionados. Hoy en día, es una norma aceptada que las personas dementes no son punibles porque quien quiera que sea incapaz de comprender la acusación y sanción no debería ser condenado.
Respecto a la carga de la prueba, de acuerdo con las reglas generales, aquél que afirma debe tener pruebas. En relación con el derecho civil, esta regla es aplicada sin excepción y el defensor, quien asegura algo, debe probar lo que declara. Acerca de casos penales, sin embargo, esta norma no podría ser aplicada como derecho civil y se dice que el fiscal debe probar todos los elementos por los que se comete un delito. La carga de la prueba, incluso cuando el acusado afirma algo, le corresponde al fiscal. Sobre la demencia, la pregunta es si la carga de la prueba le corresponde al acusado que declara demencia, o el fiscal tiene que desmentir lo que el acusado afirma. Este artículo intenta buscar una respuesta a esta pregunta en una dimension diferente de la demencia y responsabilidad penal y analizar sus condiciones en la justicia penal iraní.

\section{PALABRAS CLAVE}

Mentalmente enfermos, demencia, Irán, justicia.

\section{RESUMO}

Como regra, como todos os outros sistemas legais criminais em outros países, no direito penal iraniano, as pessoas insanas estão isentas de responsabilidade criminal. 0 primeiro Código Penal, ratificado em 1925, reformado em 1973 e abolido em 1982, classificou os doentes mentais em dois grupos. Aqueles que eram completamente insanos estavam livres de responsabilidade criminal, mas outros que sofreram de doenças mentais leves tinham diminuído responsabilidade. A seção 149 do Penal islâmico ratificado em 2013 sustenta que se o autor é mentalmente perturbado no momento de cometer o crime, de tal forma que eles não têm vontade ou poder de entendimento, eles estão isentos de responsabilidade criminal. Portanto, parece que o novo código se refere ao item A do artigo 36 do Código Penal iraniano, ratificado em 1973

O problema é que certas pessoas sofrem de uma doença mental particular ou sofrem de doenças mentais leves; no entanto, não são mentalmente nem psicologicamente loucos. $\mathrm{Ou}$ seja, embora estas doenças influenciem tanto a sua faculdade de tomada de decisão e seu comportamento, a lei reconhece-los com plena responsabilidade criminal. Assim, aparentemente a lei anterior tinha mais conformidade com 
as regras científicas. Na prática, os tribunais consideram esses casos como instâncias de circunstâncias atenuantes.

Um segundo problema é com casos onde os infratores estavam sãos quando de cometer o crime, mas depois perderam sua sanidade, mas a lei os pronuncia como totalmente passíveis de punição. Hoje em dia, é uma regra aceita que os loucos não são puníveis, porque, quem é incapaz de compreender a acusação e punição não deve ser punido.

Quanto ao ônus da prova, de acordo com uma regra geral, quem afirma deve provar. No direito civil, esta regra é aplicada sem exceção e o réu, que afirma algo, deve provar a sua reclamação. Em relação aos processos penais, no entanto, esta regra não poderia ser aplicada como no direito civil e é dito que o promotor deve provar todos os elementos por que o crime foi cometido. 0 ônus da prova, mesmo quando o acusado afirma alguma coisa, está no procurador. Quanto à insanidade, a questão é se o ônus da prova é ou não sobre o acusado que alega a insanidade, ou sobre o promotor que tem de refutar a alegação feita pelo acusado. Este artigo tenta encontrar uma resposta a esta pergunta e as dimensões diferentes da insanidade e da responsabilidade penal, e revê as condições na lei penal iraniana.

\section{PALAVRAS-CHAVE}

Doente mental, insanidade, Irã, justiça.

\section{INTRODUCTION}

Mental illnesses cover an extensive range of illnesses and the concept of mental illness is much wider than that of insanity. That is to say, insanity is the extreme type of mental illnesses, which should hinder criminal responsibility. ${ }^{1}$

The legislator does not regard all classes of perpetrators as being equal either. What is of major significance in process of criminality is intention of a perpetrator to breach the laws. This intention which, in penal terminology is called mens rea is either potentially or both potentially and actually non-existent in certain criminals: the insane belong to the latter group. ${ }^{2}$

The lack of criminal intention in the insane can imply the lack of a criminal state of mind and furthermore the lack of elements of crime, and so non-realization of any crime. Nevertheless, the legislator taking into account certain consideration, including protection of public order in society, considers such acts as criminal acts. The reason for this leniency can be the fact that owing to humanistic views of certain philosophers and criminologist in modern days, the insane exempt from any criminal liability, which was not the case in older times. Medieval law, about insane criminals, did not recognize elimination of criminal liability, and more often insane criminals punished at the gallows, even when they had not committed any crime of any sort. The society regarded them as demonic criminals, whipped to exorcise their evil spirits. It was so until late eighteenth century that certain psychologist, particularly Pinel and Esquirol, started to study insanity thoroughly, and thanks to these studies, the French Penal Code of 1810 granted criminal liability exemption to the insane. ${ }^{3}$ Thus it has been established that the insane are not legally answerable.

\section{METHODOLOGY}

The method used is an analytical method. The author has referred to different sources and after considering them, has developed the subject analytically and considered the different aspects of the topic in the Iranian criminal justice.

\section{CONCEPT OF INSANITY AND THE COURSE OF LEGISLATION}

There is a close relationship between insanity and a criminal state of mind. In other words, to prove a criminal state of mind there ought to exist certain fundamental elements, including the ability to think and discern. Insane people do not have the power to discern the nature of their committed crimes due to the certain mental disorders. To further explain the relationship between insanity and a criminal state of mind, the first section of the article, deals with the concept

1. Azmayesh, Dr Ali, lectures in Public Criminal Law, Second semester of years 2010-2011, faculty of Law and Political Science, Tehran University \& Dr Parviz Saneei. (2010). Public Criminal Law. Khatte Sevvom, p. 512.

2. Azmayesh, Dr Ali, op. cit.

3. Dr Parviz Sanei. (2010). Public Criminal Law. Khatte Sevvom, p. 502 
of insanity, and the second section entitled 'The Case of Insanity in the Course of Legislation' considers the state of the insane and the mentally ill during and after the time of committing a crime.

\section{(1) Concept of Insanity}

Insanity plea consists the principal that most sane people observe the law, but certain people due to cerebral infirmities lack the ability to do so. Thus, "an accused of a crime with a mental illness who has lost the ability to discern the nature of his illegal action and it's contrary to established laws, legally defined as insane. Mental disorder is any illness with significant psychological or behavioral manifestations that is associated with either a painful or distressing symptom or an impairment in one or more important areas of functioning. Mental disorders, in particular their consequences and their treatment, are of more concern and receive more attention now than in the past. Mental disorders have become a more prominent subject of attention for several reasons. They have always been common, but, with the eradication or successful treatment of many of the serious physical illnesses that formerly afflicted humans, mental illness has become a more noticeable cause of suffering and accounts for a higher proportion of those disabled by disease. Moreover, the public has come to expect the medical and mental health professions to help it obtain an improved quality of life in its mental as well as physical functioning. In addition, there has been a proliferation of both pharmacological and psychotherapeutic treatments. The transfer of many psychiatric patients, some still showing conspicuous symptoms, from mental hospitals into the community has also increased the public's awareness of the importance and prevalence of mental illness.

There is no simple definition of mental disorder that is universally satisfactory. This is partly because mental states or behavior that are viewed as abnormal in one culture may be regarded as normal or acceptable in another, and in any case it is difficult to draw a line clearly demarcating healthy from abnormal mental functioning."4 "There are many causes of mental disorders. Your genes and family history may play a role. Your life experiences, such as stress or a history of abuse, may also matter. Biological factors can also be part of the cause. A traumatic brain injury can lead to a mental disorder. A mother's exposure to viruses or toxic chemicals while pregnant may play a part. Other factors may increase your risk, such as use of illegal drugs or having a serious medical condition like cancer."5 So, "The capacities assumed by the law may not be present in those who are mentally disordered."6 That is why the legislator shows leniency to such cases. ${ }^{7}$

The legislator has recognized this leniency in almost all penal codes. The Iranian Penal code of 1973 did not consider undiscerning people as criminals, and recognized the ones who suffered from partial disorders of their sense of judgment and understanding as having reduced criminal liability. The Islamic Penal code of 1982 and its 1991 note, rather unreasonably, and to some extent illogically, annihilated such distinctions and proposed criminal exemption due to any degree of insanity. But, new Penal Code, ratified in 2013 has come back to the first section of article 36 of Penal Code ratified in 1973, but ones who suffered from partial disorders of their sense of judgment and understanding have full criminal liability.

Diagnosis of insanity, although is a substantial and specialized issue, but the legislator has allowed the considerations made by non-experts in the course of investigation to be taken into account alongside certified expert diagnosis. According to article 202 of criminal procedure code, ratified in 2014 and came into force since 22/06/2015, "whenever, in the course of investigation, the interrogator considers probable that the accused was insane at the time of committing the crime, asks the forensic medicine to visit the accused. If he acknowledges his insanity, the interrogator stops the prosecution and sends the file to the prosecutor. If the prosecutor agrees with him and the insanity continues, in the case of necessity, they send the insane to the special centers for insane people." According to article 370 of the same code, "if in the course of trial, the court considers probable that the accused was insane

4. Andrews, Linda. Retrieved from: http://www.britannica.com/ science/mental-disorder

5. U.S. National Library of Medicine, Mental disorders. Retrieved from: http://www.nlm.nih.gov/medlineplus/mentaldisorders.html

6. Andrew Ashworth, (2006), Principles of criminal law, fifth edition, Oxford University Press, p. 26.

7. U.S. National Library of Medicine, Mental disorders. Retrieved from: http://www.nlm.nih.gov/medlineplus/mentaldisorders.html 
at the time of committing the crime, will do the necessary investigation through his relatives and other informants, and asks the forensic medicine to visit the accused. If the court realizes his insanity stops the prosecution and then decides if the security measure are necessary or not." There is a similar idea in the Canadian criminal law. It is told "Those suffering from mental illness, no less than children, pose an obvious problem for the criminal law. On the one hand, morality and law have always regarded people not in their right mind as not responsible for their actions and not in fairness blamable for them. On the other hand, protection of the public interest demands that where such lack of responsibility results in danger to others, such people should not be left at large."8

"As a psychological term, insanity is an extreme case of psychosis which deranges the natural function of the person's mind, disrupting his mentality, conduct, emotions, and actions. Insanity often diagnosed by its accompanying symptoms including loss of the sense of reality, blurred understanding, retrogressive and childish behavior, loss of self-control, instinctive conduct, abnormal thoughts, delirium, and hallucinations. It may also cause deterioration and habitual weakness of character which at times necessitates hospitalization of the individual." 9 Thus, insanity as a case of psychosis includes schizophrenia, hypomania, mania, depression, etc. Four other types of mental illnesses including melancholia, character disorders, psychosomatic disorders, and mental retardation are not classified as instances of insanity. ${ }^{10}$

Contrary to the prevailing view, which regards insanity as eliminating criminal responsibility, it ought to hinder the establishment of any suchlike responsibility, because it rather obstructs foundation of any criminal responsibility than eliminating it after establishment.

8. Law Reform Commission of Canada (1982), Criminal Law, The General Part: Liability and Defences, $p .41$.

9. Bahrami, Dr Gholam Reza, Dictionary of Psychiatry and Psychology. Tehran, Tehran University Publications, 1968. p. 190.

10. . Hekmat, Dr Saeid, Penal Psychiatry, Tehran. Toos Publications, 1995. p. 133.

Fadaei, Dr Farbod, Psychiatry for all, Tehran. Bozorgmehr Publications, 2001. p. 80.

Farzad Birjandi, Dr Parvin, Psychology for Abnormal Behavior Tehran, Dehkhoda Publications, 2001. p. 190.

Keynia, Dr Mehdi, criminal psychology, Tehran. Roshd Publications, 1995. p. 399.

\section{(2) The Case of Insanity in the Course of Legislation}

There are many flaws in the Iranian Criminal Code about the case of insanity. The study of the course of legislation implies that the legislator has not been consistent in his criminal policy. To clarify the issue the following sections of the present article considers it in two parts, namely:

(1) The conditions during the time of committing the crime, and

(2) The conditions after the time of committing the crime. The first part is a chronological study of the Penal Codes of 1925 and 1973, and the Islamic Penal Codes of 1982 and 1991 and 2013.

\section{(1) The Conditions at the Time of Committing the Crime}

Each of the following codes have provided different provisions about the situation of criminal liability and insanity, which we consider them as follows:

\section{1- The 1925 Penal Code}

Section 40 of the first Iranian Penal Code ratified in 1925 which was inspired by ideas of the classic and neoclassic schools stated that "anyone who is insane or suffers from cerebral disorders when committing the crime is not considered a criminal and is not punishable, but shall be referred to a lunatic asylum should his insanity endure."

The legislator of the 1925 Code had used the terms 'insane' and 'cerebral disorders' to refer to a wider range of mental disorders. That is to say that, the legislator had not limited criminal liability exemption to the insane but also to a wider range of non-insane criminals who suffered from cerebral disorders. The problem was that, the legislator had classified the criminal at the time of committing the crime as sane and insane, and had not recognized a medium stage in the case. Because, if we extend the definition of cerebral disorders to cover the disorders that do not totally disrupt the power of reason and discretion but make the person unhealthy and unwholesome, then the question is, why should these people exempt from criminal liability while they do not really have the conditions thereof? On the other hand, if we do not apply the aforementioned disorders to such people, the question is why they should bear equal liability to that of healthy. It would have been better if the legislator had elucidated his definition of insanity and cerebral 
disorders. The other problem with the Code was that, it had mentioned the referring of the insane to lunatic asylums, and no mentioned was made of the fate of criminals with cerebral disorders who were exempted from criminal liability but nonetheless could be a menace to society.

The term 'cerebral disorders' principally referred to such mental disorders as acute mental retardation, intense depression, and degenerative hysteria thereby the person loses his discretion and volition totally. Nevertheless, application of this term to mental illnesses that entice a person who has not totally lost his volition and discretion to commit crimes, such as kleptomania and moral indiscretion would not be far-fetched. That is why certain jurists regard cerebral disorders to apply to illnesses such as moral discretion, and disorders of volition, sleep, alcoholism and deafness and dumbness. ${ }^{11} \mathrm{~A}$ person with a disability (moral discretion) has lost a clear conscience and the power of discretion of good and evil, right and wrong. In contrast, a healthy person is criminally liable. A Kleptomaniac who is under the influence of the loss of self-control and tempted to crime due to excitement and provocation are heedless in the face of committing a crime. ${ }^{12} \mathrm{~A}$ kleptomaniac neither needs nor desires the stolen object, but he is rather sexually aroused by the act of theft. ${ }^{13}$

In the aforementioned section of the Code the legislator had used the phrase ' is not considered a criminal and is not punishable' instead of criminal exemption. Jurists had proposed different interpretations of the phrase. Some have argued that since 'insanity and cerebral disorders' obliterates mens rea which is an indispensable element in the realization of crime, the legislator had originally meant to refer to the non-criminality of the committed crimes in the real sense of the word. ${ }^{14}$ Some, inferring that since insanity hinders the criminal from being charged with crime, have taken the intention of the legislator to refer to exemption of criminal liability. ${ }^{15}$

11. Baheri, Dr Mohammad, public criminal law, Tehran. Elmi Publications, 1961. p. 243.

12. Dadban, Dr Hassan, Translation of public criminal law, Jeorge Luvasor and Bernard Bulock, Tehran. AllameTabatabaei Publications, 1998. p. 522 .

13. Sannei, Dr Parviz, (1978), Translation of Penal Psychology, (David Ibrahamson). p. 186.
Regardless of what the phrase 'is not considered a criminal and is not punishable' stated in the 1925 Penal Code really denoted, it seems that the action of the insane should not be considered a crime. Since materialization of a crime is dependent on the three elements of legality, actus reus and mens rea, the insane thus lacks the last element of mens rea. To have mens rea the person should potentially and actually have the power of thought, and the insane lacks the power of thought both potentially and actually. Lack of the power of thought entails the lack of reason, which is the essential element of criminal intention. Therefore, the essential element of a criminal state of mind viz. malice aforethought is principally non-existent.

Apparently the legislator has not followed this theory and considers the action of the criminal as crime, only to exempt him from criminal liability. The reason thereof is that, the legislator cannot ignore the social consequences of the action of an insane criminal. Since, the crimes committed by the insane have the same social consequences as those committed by the sane. Only the reaction to the crimes of the insane is different and bears some leniency. ${ }^{16}$

\section{2- The 1973 Penal Code}

The 1973 legislator, due to new criminologist approaches of the day, amended Section 40 of the 1925 Penal Code. In Chapter 8 of the Code, Section 36 provided that:

"(a) Whenever it is ascertained that the perpetrator due to either congenital or accidental causes had lost the faculty of reason or total disorder of discretion or volition while committing the crime, he shall not be considered a criminal. If he is verified to be in a menacing condition, by the order of the prosecutor he shall be kept in a suitable place until recovery, and his release will be due to the order of the prosecutor.

(b) If the perpetrator had suffered from partial disorder of reason, discretion or volition during the time of committing the crime as to influence the commitment of the crime, the punishment thereof is as follows."

\section{Baheri, Dr Mohammad, op. cit. p. 240.}

15. Saneei, Dr Parviz, op.cit. p. 512.

16. Azmayesh, Dr Ali, Public Criminal Law. Op.cit. 
The items enumerated in Paragraph (b) of Section 36 implied a mitigated state of punishment. Hence the legislator had mitigated the punishment of the criminals suffering from partial mental disorders, thus implying reduced criminal liability of the above-mentioned criminals. ${ }^{17}$

Paragraph (a) of the above section had used the phrase "congenital or accidental causes" instead of "congenital or accidental illnesses". The phrase "causes" covers a broader sense than "illnesses" and thus can be extended to apply to cases which are not illnesses but can cause total disorder of reason, discretion or volition. In other words, the legislator did not mean only the pathological side of the issue. For instance, disorders grounded in social, familial and educational-instructive causes are liable to the above law. Congenital causes refer to inborn qualities. Some of these qualities are shared by man and animals alike and make up the instincts and others are limited to man. ${ }^{18}$ It is clear that the phrase in the above mentioned section refers to the latter qualities.

Hence, congenital causes include all inherited maladies and disorders as well as defects at birth and racial qualities which are born with the person; accidental causes on the other hand refer to all temporary and acquired psychotic states of mind.

The loss of reason denotes the lack of the faculty of thought and understanding, including the inability to differentiate reality from unreality. Conceptual disorders include delirious visions, blurred understanding and hallucinations. In such case the person is unable to discern the relationships between objects and affairs, and is totally unable to understand even the simplest issues.

17. Section 36 of the 1973 Penal Code stated: "Whenever it is ascertained that the perpetrator due to either congenital or accidental causes had lost the faculty of reason or total disorder of discretion or volition while committing the crime, he shall not be considered a criminal. If the perpetrator had suffered from partial disorder of reason, discretion or volition during the time of committing the crime as to influence the commitment of the crime, the punishment can be mitigated by one or two degrees provided it won't be thus less than minimum correctional imprisonment. And the correctional punishment of the perpetrator is the minimum correctional imprisonment which can be converted to financial penalty."

18. Nafisi, Dr Saeid, Nafisi Dictionary, volume 5, Tehran. 1955. p. 528.
Total disorder of discretion signifies a state, where the person cannot differentiate good from evil, or right from wrong, hence being unable to judge. "If a person has lost the power of discretion and choice, he cannot be blamed for his actions." ${ }^{19}$ Some regard this disorder to be the effect of having been brought up under certain social and cultural circumstances. Social values and norms are relative entities and the nature of an individual's conduct is dependent on his socialization under certain circumstances. Thus, the set of moral values held by different people is directly determined by the different circumstance under which they have been socialized. Therefore if certain social norms necessitate the acquisition of a criminal conduct, it would be unfair to punish a criminal who has committed a crime which was an ordinary way of life in the community he had been brought up. So, it is possible to attribute total loss of discretion to certain people who have been brought up in such like communities. If such a case is verified, then criminal liability would be eliminated, provided that it had actually existed at the time of committing the crime. ${ }^{20}$

Other causes including natural or induced sleep, intoxication and consumption of narcotics can cause total disorder of volition. The cause thereof is not important, but what is significant is the existence of such a disorder.

The 1973 Penal Code had not actually used the phrase "other mental illness", but the extent of the ordained decrees of total or partial disorder of reason, discretion and volition was such as to include all cases of mental illnesses including total or partial insanity. It can be said that the 1973 Penal Code, with regard to mental illnesses, was a comprehensive one based on scientific rules of the day, but unfortunately after the Iranian Islamic Revolution, the legislator, quite illogically, abandoned all the above-mentioned rules.

\section{3- Post-Revolutionary Penal Codes}

As was mentioned, Section 27 of the 1982 Islamic Penal Code, following a retrogressive trend ignored the principles on total or partial criminal exemption about mental illnesses and solely specified a single rule about insanity. According to this rule "insanity of any degree

19. Ardebili, Dr Mohammad Ali, public criminal law, volume 2, Tehran. Mizan Publications, 2014. p. 75.

20. Saneei, Dr Parviz, op. cit. p. 513. 
entails criminal exemption." The note to the above section stated that "about periodic insanity, insanity at the time of committing the crime is intended." The same rule, with slight changes in the wording, repeated in section 51 of the 1991 Islamic Penal Code, which states that "insanity of any degree at the time of committing the crime entails criminal exemption." Note 2 of the above section asserts that "about periodic insanity, only insanity at the time of committing the crime entails criminal exemption."

Apparently in the view of the postrevolutionary legislator perpetrators were either sane or insane, and a medium state is undefined. As a psychological term insanity denotes "psychosis". Regarding the criminal exemption of perpetrators the legislator had gone to such extremes as to drop the distinction between a simple case of schizophrenia and critical psychosis. What the legislator intended was to have the perpetrator identified as psychotic and the degree of the disorder had been insignificant to him. It is clear that such a phrase was absolutely irrelevant to law principles. Therefore, the legislator ought to avoid a phrase contrary to law principles, and elaborate in details the existing difference between various degrees of insanity. Exempting slightly psychotic criminals seems to be an irrational.

The other flaw of the post-revolutionary was that it had totally ignored other kinds of mental illness except for insanity and psychosis. Although some believe that the legislator by employing the phrase "insanity of any degree" had intended to extend criminal exemption to all mental illnesses on the border of sanity and insanity, ${ }^{21}$ It is clear that the individual's mental illness is either labeled as insanity or not. If it is considered as insanity then he is granted criminal liability exemption, and if it is not considered as insanity then he is criminally liable. Therefore it is impossible to consider any criminal on the fine line between sanity and insanity. Furthermore certain people suffer from mental illnesses other than insanity: to regard them as criminally liable is as much unfair as to grant full criminal exemptions to slightly psychotic criminals.

If criminal exemption is based on lack of reason and discretion, then these conditions can

21. Noorbaha, Dr Reza, op. cit. p. 340. be true about many other people with mental illnesses. For instance, people with acute mental retardation, degenerative hysteria and intense depression belong to the latter group, and there ought to be no legal difference between them and other mentally ill people.

Seemingly, the post-revolutionary legislator had founded the decree on religious jurisprudence, in which mention has been made of the criminal exemption of only the insane. Due to the fact that certain mental illnesses are findings of modern psychology or the consequences of life in a problematic modern world, such cases were not taken into consideration in the religious law of older periods, and the religious legislator had refrained from issuing any verdict thereof, because he was either unable to do so or did not find it necessary.

Thus, one of the cases which the judge should have taken into consideration was psychotic states which are not regarded as insanity. The degree of the disorder can allow the judge to alter the degree of mitigation. Thus the judge could approximate the case of mentally ills that are not considered as insane with the concepts stated in Section 36 of the 1973 Penal Code. Nevertheless, it was clear that the nature of the verdict thus issued was different from those which could be issued according to Section 36 of the abovementioned Code.

But, in 2013 the legislator reformed the Islamic Penal Code. According to article 149 of the new code, if the offender at the time of commission of an offense suffers from a mental disorder in a way that $\mathrm{s} /$ he has no intention or sense of discernment, $\mathrm{s} /$ he shall be regarded as insane and has no criminal responsibility. According to article 150 " If, at the time of commission of the offense, the offender is insane, or $s /$ he becomes insane after the occurrence of the offense, and his/her insanity and dangerous state is established by a specialist, by the order of public prosecutor, $\mathrm{s} /$ he shall be kept in a proper place until such a dangerous state is ended. The detainee or his/her relatives can protest this order to the court; in such a case, the court, in the presence of the protestor, and considering the opinion of the specialist, shall consider the issue in an administrative session and decide to either release the detainee if it believes that the dangerous state is ended or confirm the prosecutor's order. The decision shall 
be final, but the detainee or his/her relatives shall be entitled to protest against the decision if the detainee shows signs of improvement.

Note 1- If an offender of one the offenses punishable by hadd, becomes insane after the final judgment is delivered, the hadd punishment shall not be removed. If the insanity occurs before the final judgment is delivered, in the cases of hadd offenses that fall under the group of huquq-ullah (claims of God) the prosecution and trial shall be postponed until [the offender] is recovered. In the cases of offenses that fall under the group of huquq-un-nas (claims of people) such as qisas and diya, also in which losses and damages resulted from the offense, insanity shall not prevent the prosecution and trial.

Note 2- The Judiciary is obliged to supply centers of security measures for keeping such people in every judicial district. Until such centers begin their work, one part of psychotherapy centers of welfare organization or available hospitals shall be allocated for such people."

Note 1 is partly in conflict with note 2 of article 13 of Criminal Procedure code ratified in 2014 (later than Islamic Penal Code). According to note 2 of article 13 in all cases of huquq-un-nas (claims of people), if the perpetrator is insane, the court should distinguish between two situations:

1- The court believes that even if the perpetrator was sane, he could not defend himself. In this case the parents of the perpetrator or his legal representatives are asked to appoint a lawyer, and if they refuse, the court himself appoints a lawyer.

2- The court believes if the perpetrator was sane, he could defend himself and prove that the given evidences are invalid. In this situation, the court suspends the trial.

The same situation is in Germany with regard to lack of criminal liability. According to article 20 of the penal code "Any person who at the time of the commission of the offence is incapable of appreciating the unlawfulness of their actions or of acting in accordance with any such appreciation due to a pathological mental disorder, a profound consciousness disorder, debility or any other serious mental abnormality, shall be deemed to act without guilt." Article 21 refers to the diminished responsibility and provides "If the capacity of the offender to appreciate the unlawfulness of his actions or to act in accordance with any such appreciation is substantially diminished at the time of the commission of the offence due to one of the reasons indicated in section 20, the sentence may be mitigated following section $49 . " 22$

\section{1- The Conditions after the Time of Committing the Crime}

According to Paragraph 1, Section 8 of the 1911 Iranian Penal Code, which is now abolished, the insanity of the perpetrator or the accused was considered an instance resulting in the suspension of prosecution. Section 89 of the same Code demanded that "whenever during the course of investigations, the interrogator observes that the accused is insane or not sound of mind, he shall ask the opinion of a physician and having consulted the acquaintances and relatives of the accused, go ahead to record the findings in the minutes and send the case to the preliminary public prosecutor. If the prosecutor, having considered the case, certifies the investigations carried out by the interrogator and experts, he shall send the case to the interrogation department, while the insane or the mentally deranged person is referred to a proper bureau for required further measures. If the prosecutor does not certify the preceding investigations, he may do further investigations by inquiring other expert opinion." Section 90 of the above Code asserted that "when signs of insanity or mental derangement in the accused appear after preliminary investigations and interrogation, prior to trial, investigations are to be carried out at the criminal or correctional court." According to the 1929 Insanity Code "when the person convicted to imprisonment, goes insane before the termination of the imprisonment term, with the certification of a forensic expert, he shall be immediately transferred to the nearest lunatic asylum. The period of residence in the lunatic asylum shall be calculated as a part of his imprisonment term."

Section 37 of the 1991 Islamic Penal Code also stated that "when a convict goes insane prior to the termination of the imprisonment term, with the certification of a forensic expert verifying his insanity, he shall be transferred to a mental hospital. The period of residence in the hospital shall be calculated as a part of his imprisonment

22. https://ec.europa.eu/antitrafficking/sites/antitrafficking/files/ criminal_code_germany_en_1.pdf 
term and in case a mental hospital is not available, the convict shall be kept in an appropriate place determined by the prosecutor."

Unfortunately, note 1 of section 150 of Islamic Penal Code ratified in 2013 does not allow stop of punishment in crimes called Hodood, ${ }^{23}$ only before the verdict becomes final, the prosecution is suspended and in crimes in which there is private complainant, the insanity does not influence the prosecution or performance of punishment. That is against criminal principles, since the insane criminal is unable to comprehend the running issues as to be reformed by punishment. Moreover rehabilitation of an insane criminal is legally impossible before his full recovery from insanity. On the other hand his punishment can by no means set an example for other people, because his case is viewed as being exceptional: rarely do sound and sane people find themselves with an insane criminal. ${ }^{24}$

\section{2- Relation between Insanity, Mens Rea and Burden of Proof}

Public criminal law books discuss actus reus prior to mens rea. That is because of the relation between mens rea and criminal liability, however, principally, the issue of mens rea is prior to that of actus reus. Because, initially a criminal state of mind is created in the person, and then the intention is materialized in the outside world. Nonetheless, whether mens rea is discussed prior to actus reus or vice versa, there exists a close relationship between the former and criminal liability. Hence, the first section of the present part of the article deals with the relationship between insanity, as a major issue about criminal liability, and mens rea, whereas the second section is concerned with the burden of proof in cases of insanity plea.

(1) Relation between Insanity and Mens Rea

As was mentioned before, mens rea is the major principal in the materialization of crime and criminal liability. Because, in the course of criminal prosecution, the legislator does not solely confine himself to consideration of actus reus, and ultimately those people who had the intention

23. Hodood are crimes which their punishment has been determined in Islāmic Law, like adultery, Buggery, fornication, Rape, Drinking alcohol.

24. Saneei, Dr Parviz, op. cit. p. 509. of violating a established law are prosecuted and punished. Such an intention entails first, awareness of the existence of the law, secondly, awareness of the subject, thirdly intention of violation, and in certain cases intention of gaining a criminal result or motivation is also added to the three above mentioned states. Hence, it cannot be said that all perpetrators of crime have had the necessary mens rea for the crime.

Furthermore, legally only people who have the faculty of thought and the volition to break the law have criminal liability, and those people lacking the faculty of thought, and so mens rea are ultimately exempted from criminal liability. Nevertheless the legislator having responsibility to maintain public peace and quiet has regarded the actions of aforementioned people as crime, because the menacing social consequences of the crimes committed by such people is equal to those of others. ${ }^{25}$

Legally speaking "depending on whether we consider the lack of mens rea denoting nonmaterialization of crime, or insanity eliminating criminal liability, different legal courses ought to be adopted. If we accept the idea that a perpetrator who had been insane or mentally disordered at the time of committing the crime is not basically considered a criminal, then the prosecutor shall order prohibition of prosecution; but if consider insanity at the time of committing the crime as entailing criminal exemption, then the order of suspension of prosecution shall be issued." 26

It seems necessary to set up a relationship between mens rea and proof of sanity at the time of committing the crime, to further explain the issue at hand. That is to say, there exists a close relationship between the required proof of sanity at the time of committing the crime, and the required existence of mens rea for the materialization of the crime. To put it more exactly, it should be said that since Penal Codes essentially regard only people who have the intention of violating established laws as criminals and liable to punishment, and the insane are incapable of possessing such an intention while

25. . Dr Ali Azmayesh, Lectures on Public Criminal Law. Op. cit.

26. Ashouri, Dr Mohammad, criminal procedure, volume 1, 7th edition, Tehran. Samt Publications. 2002. p. 177. 
the prosecutor should prove the existence of malice forethought-and the existence of malice aforethought requires a sound mind-to prove such an intention necessitates the existence of its most fundamental element of reason.

"If the accused pleas simultaneously insanity and lack of mens rea due to the effects of mental disorder, and the existing evidence proves his inability to comprehend the nature and quality of his committed actions, the above evidence not only proves the plea of insanity, but it also creates a reasonable doubt about the necessary prerequisite for malice forethought."27

\section{(2) Burden of Proof}

As a rule the prosecutor should seek to prove all the components of crime, including mens rea. In the case of insanity, the question is whether the accused of the case, who has claimed insanity at the time of committing the crime or afterwards, should seek to prove his claim or it is the task of the prosecutor to prove the sanity of the accused, or else it is enough for the accused to plea insanity. In other words, in the case of plea of insanity who bears the burden of proof? Should an accused who has claimed insanity at the time committing of the crime prove his insanity before he is exempted from criminal liability? - based on the general principle that the claimant is to prove his claim-or should the prosecutor disprove his claim?

It should not be inferred from the above issue that in the case of the prosecutor proving the non-existence of insanity, it is supposed that all people are insane, unless the opposite is proved. Such a supposition is neither reasonable nor logical. It is rather supposed that the prosecutor is to prove all the components of crime and the conditions which make it prosecutable, one of which being the principal of the awareness of the perpetrator of the nature of his action. Because, if the criminal does not have total mental health at the time of committing the crime, he is unaware of the nature and quality of his actions and is unable to differentiate right and wrong, thus he will be incapable of explaining his committed actions afterwards.

27. Thomas,Lundy, www.juryinstruction.com/article_section/ articles/article/article49.htm.
No explicit reference has been made about the burden of proof in the case of plea of sanity in the Iranian legal system. Hence reference should be made to jurisprudence. A survey of earlier verdicts is indicative of the fact that the prosecutor had to prove the sanity of the accused. For instance, the verdict issued by a branch of the Iranian Supreme Court-numbered 2/335/71-concerning a case of kidnapping reads as follows: "it is unacceptable to believe that a person has attempted kidnapping with a motorcycle in public and in broad daylight, and if such an act has been actually committed, it is indicative the fact that the accused did not have a sane mind, although mention of it has been made in some of the reports, and the court or the prosecutor's office had to refer the case to an expert to prove or disprove the sanity of the accused...." ${ }^{28}$ Verdict number 2/67/72 of the Supreme Court reads: "the evidence documented in the case, especially medical certifications and the opinion of the medical council show that the denotations of the concept of insanity are different in custom, language, religion and law; generally speaking, the conviction of an individual who is not answerable for his actions, and with regards to the literary denotation of insanity which refers to degeneration and deterioration of reason, as well as taking into consideration that law grants criminal exemption to the insane with any degree of insanity, it is evident that further acquisition of expert medical opinion, and further investigation is required for the establishment of exemption from criminal liability."29

As is seen, in the above cases, the court had the responsibility of investigating the state of sanity of the accused; even though the accused had not claimed insanity nor offered any evidence thereof. It should not be supposed that the Iranian legal system holds people as insane unless the opposite is proved, but like legal systems of other countries, the Iranian one is also based on the presupposition of sanity. Nonetheless, as was mentioned before and is indicated by the above cases, the sanity or the insanity of the accused is the basis for the existence or non-existence of malice aforethought, respectively.

28. Yadollah Bazigar, Reasons for the Reversal of Criminal Verdicts, Verdict number 259, p. 322.

29. Yadollah Bazigar, Reasons for the Reversal of Criminal Verdicts, p. 148. 
In the first verdict the responsibility of proving the sanity of the accused was laid on the court or the prosecutor's office, and the burden of proof was considered a part of their task. And it can be implied from the second verdict that the burden of proof is on the prosecutor, and he should, with reference to a medical expert, prove that the accused had been sane at the time of committing the crime.

The verdict numbered 20/798/70-1 issued by another branch of the Supreme Court has referred to the issue mentioning that "the appeal of the accused has announced that he is mentally ill and has a record of hospitalization at a mental hospital, thus no judgment has been made in regards to the above fact, while the proof or disproof of the claim is an essential element for passing judgment, therefore the previous judgment is nullified. ${ }^{30}$ Contrary to the explicit reference made to the responsibility of the prosecutor in such cases, the legal bureau of the judiciary in response to a question asked by the Head of Branch 34 of Tehran's Court of Appeal declared its view dated June 29, 2005, number $7 / 2624$ as follows: "If at any time during the course of defense, the accused claims instances entailing criminal exemption-for instance, to plea periodic insanity and state that he had not recovered fully at the time of committing the crime-he should send required evidences such as medical certifications, etc. to support his claim. The judge should then investigate the verity of the claim and the pertaining evidence. But in cases such as those barred by statute of limitations, even if the accused is not aware of the circumstances, the judge is responsible for observing the law and enforcement of the regulations of statute of limitations."

Nonetheless, the abovementioned view does not imply that the burden of proof of insanity is on the accused, but rather whenever the accused makes the judge doubtful of his state of sanity at the time of committing the crime, the prosecutor should prove the sanity of the accused. In any case, the issue should be referred to a medical expert, and criminal exemption cannot be held back just because the accused fails to prove his insanity. In other words, the accused can offer evidence to make the judge doubtful of his sanity, and thus the burden of proof is lifted from the accused and will be on the prosecutor.

\section{CONCLUSION}

Psychological advances regarding the diagnosis of medical illnesses have enticed legislators of different countries to consider the possibility of granting criminal exemption to the mentally ill, or to regard them as liable to mitigated circumstances. The significance of such advances is indicative of the dependence of criminal laws on psychology; and day by day new psychological findings are achieved in the study of mental illnesses.

But unfortunately, after the Iranian Islamic Revolution, the Iranian legislator had adopted a retrogressive course in legislations about mental illnesses. Despite the fact that the Iranian 1973 Penal Code complied to a great extent with the medical and scientific principles of the day, the post-revolutionary legislator abandoned the scientific principles stated in the 1973 Penal Code and ratified certain problematic rulings.

The post-revolutionary legislator ignored mental illnesses rather than insanity which could entail criminal exemption or mitigation, thus causing certain discrepancies in the case of individuals with severe mental illnesses who were regarded as insane: in such cases the largest degree of leniency allowed to the court was to consider mitigating circumstances of criminal liability.

Fortunately, new Penal Code ratified in 2013 has somehow come back to Penal code 1973 and has provided if the perpetrator suffers of mental disturbance totally, he will be exempted of criminal liability, but does not refer to those who do suffer mentally disorder relatively. In the latter case the court can mitigate the punishment by referring to article 38 of the new Penal Code, according which "Specific circumstances under the influence of which the accused has committed the offense" is one of the mitigating factors and according to article 37 "If there is one, or more, mitigating factor(s), the court may mitig 


\section{BIBLIOGRAPHIC REFERENCES}

- Ashworth, Andrew, (2006), Principles of criminal law, fifth edition, Oxford University Press.

- Ardebili, Dr Mohammad Ali, public criminal law, volume 2, Tehran. Mizan Publications, 2014.

- Ashouri, Dr Mohammad, criminal procedure, volume 1,7 th edition, Tehran. Samt Publications. 2002.

- Azmayesh, Dr Ali, Lectures in Private Criminal Law, second semester of years 2009-2010, faculty of Law and Political Science, Tehran University

- Baheri, Dr Mohammad, public criminal law, Tehran. Elmi Publications, 1961.

- Bahrami, Dr Gholam Reza, Dictionary of Psychiatry and Psychology. Tehran, Tehran University Publications, 1968.

- Bazgir, Yadollah, Reasons overturning of criminal writs.

- Dadban, Dr Hassan, Translation of public criminal law, Jeorge Luvasor and Bernard Bulock, Tehran. AllameTabatabaei Publications, 1998.

- Fadaei, Dr Farbod, Psychiatry for all, Tehran. Bozorgmehr Publications, 2001.

- Farzad Birjandi, Dr Parvin, Psychology for Abnormal Behavour. Tehran, Dehkhoda Publications, 2001.

- Hekmat, Dr Saeid, Penal Psychiatry, Tehran.
Toos Publications, 1995.

- Keynia, Dr Mehdi, criminal psychology, Tehran. Roshd Publications, 1995.

- Nafisi, Dr Saeid, Nafisi Dictionary, volume 5, Tehran. 1955.

- Nourbaha, Dr Reza, public criminal law, 6th edition, Tehran. Dad Afarin Publications, 2002.

- Sannei, Dr Parviz, Translation of Penal Psychology, Tehran. Ganje danesh Publications, 1991.

- Saneei, Dr Parviz, public criminal law, Tehran. Ganje Danesh Publications, 2003.

- Sannei, Dr Parviz, (1978), Translation of Penal Psychology,

- (David Ibrahamson).

- Andrews, Linda. Retrieved from: http://www.britannica.com/science/ mental-disorder

- U.S. National Library of Medicine, Mental disorders. Retrieved from: http://www.nlm.nih.gov/medlineplus/ mentaldisorders.html

- Law Reform Commission of Canada (1982), Criminal Law, The General Part: Liability and Defences

- https://ec.europa.eu/antitrafficking/ sites/antitrafficking/files/criminal_code_ germany_en_1.pdf 